\title{
POST-TRAUMATIC STRESS DISORDER AND POST-TRAUMATIC GROWTH IN DIALECTICAL PERSPECTIVE: IMPLICATIONS FOR PRACTICE
}

\author{
Pavlo Lushyn \\ https://orcid.org/0000-0002-9549-1759 \\ Scopus Author ID: $\underline{57220195344}$ \\ plushyn@uem.edu.ua \\ University of Educational Management, Ukraine \\ Yana Sukhenko \\ https://orcid.org/0000-0001-7440-2537 \\ Scopus Author ID: $\underline{57220201105}$ \\ suhenko333@uem.edu.ua \\ University of Educational Management, Ukraine
}

\section{Received January 4, 2021; Revised May 15, 2021; Accepted June 6, 2021}

\begin{abstract}
This article provides the conceptualization of the post-traumatic development (PTD) in terms of a dialectical unity of the processes of post-traumatic stress disorder (PTSD) and post-traumatic growth (PTG); practical implications for eco-centered facilitation of post-traumatic growth and development. The results of the research indicate that the process of personality development is paradoxical, irreversible and scarcely predictable. In dialectical perspective the attractor of change is not about the content of transient forms (such as trauma, success, flow) but the stabilization of their change: thesis - antithesis - synthesis. As compared to PTG, PTD's outcome is the systemic transition to the novel (not better or positive) identity. PTSD as well as PTG constitute minor cycles within the major cycle of PTD. The core metaphor of change as personality development is the work of the immunity system (SPI) which has an ambivalent nature: on the one hand, it defends the personality from the influence of adversarial agents and on the other - proactively guards it from stagnation and lack of confrontation and discontinuity. Principals of PTD facilitation: (a) the situation of psychological help (PH) is a case of a transition to a social level of personality self-regulation; (b) an inquiry for PH contains a narrative with necessary and sufficient elements for post-traumatic growth and development; (c) these elements are objectified in paradoxes, contradictions, incongruences as the source of personality development; (d) the task of PTD facilitator is to support the explication of internal change programs by maintaining the position of ambiguity tolerance and sensitivity to accidental flow of events.
\end{abstract}

Keywords: post-traumatic growth, post-traumatic development, social psycho-immunity, a transient form, eco-centered facilitation, metamodernism.

Лушин Павло, Сухенко Яна. Посттравматичний стресовий розлад i посттравматичне зростання в діалектичній перспективі: практичні імплікації.

Анотація. У статті представлена концептуалізація посттравматичного розвитку (ПТР) 3 позиції діалектичної єдності процесів посттравматичного стресового розладу (ПТСР) та посттравматичного зростання (ПТЗ); практичні імплікації для екоцентрованої фасилітації посттравматичного зростання та розвитку. Основні його результати свідчать, що процес особистісного змінювання як розвитку $\epsilon$ парадоксальним, незворотним та

\footnotetext{
(C) Lushyn, Pavlo; Sukhenko, Yana, 2021. This is an Open Access article distributed under the terms and conditions of the Creative Commons Attribution 4.0 International Licence (http://creativecommons.org/licenses/by/4.0) .

East European Journal of Psycholinguistics, 8(1), 57-69. https://doi.org/10.29038/eejpl.2021.8.1.lus
} 
малопередбачуваним. У діалектичній перспективі атрактор змін - не тільки про характер перехідних форм (таких, як травма, успіх, періоди щастя чи потоку), а й про стабільність їх змін: теза - антитеза - синтез. ПТСР і ПТЗ є фазами загального циклу ПТР. Основною метафорою змінювань як розвитку є робота імунної системи (СПI), що має амбівалентну природу: з одного боку, вона захищає особистість від впливу шкідливих агентів, а 3 іншого - проактивно охороняє від застою, відсутності конфронтації та переривчастості. Принципи фасилітації ПТР: а) ситуація психологічної допомоги (ПП) - це свідчення, приклад переходу на соціальний рівень саморегуляції особистості; б) запит на ПП містить наратив із необхідними та достатніми елементами для посттравматичного зростання та розвитку; в) дані елементи об'єктивуються через парадокси, суперечності, невідповідності як джерела розвитку особистості; г) завдання фасилітатора ПТР полягає у сприянні експлікації програм внутрішніх змін через збереження позиції толерантності до невизначеності, чутливість до спонтанного розвитку подій. Важливою передумовою ПП, що сприяє ПТР, $\epsilon$ антитезова позиція фасилітатора. Дані принципи узгоджуються 3 уявленнями про «індустрію невизначеності або ПТР» та позначають формування нових моделей самоорганізації на основі метамодерної моделі.

Ключові слова: посттравматичне зростання, посттравматичний розвиток, сочіально-психологічний імунітет, перехідна форма, екочентрована фасилітація, метамодернізм.

\section{Introduction}

One of the most significant findings over the recent twenty years of psychology development is that survivors of traumatic events (disasters, criminal violence, combat, motor vehicle accidents, and sexual assault) can experience not only posttraumatic stress disorder (PTSD) symptoms including intrusive memories, avoidance of reminders, negative alterations in cognitions and mood, and marked alterations in arousal and reactivity (American Psychiatric Association, 2013) but they will become more resilient and will express more appreciation for life, meaningfulness of relationships, personal strength, change of priorities, and increased spirituality. Tedeschi and Calhoun coined the term post-traumatic growth to describe a "positive psychological change experienced as a result of the struggle with highly challenging circumstances" (Tedeschi \& Calhoun, 2004, p. 1).

Decades of research has provided evidence that the majority of psychologists and therapists have been mostly preoccupied with a study and a treatment of negative psychological consequences which result from exposure to traumatic events (PTSD) (Brown et al, 2019; Ertan et al, 2021; Stein et al, 2020). With growth of Positive Psychology (PP) there appeared a substantial increase in the number of studies that view the negative consequences of trauma with greater tolerance, as a natural constituent or an integral part of human condition (Cohena \& Baib, 2019; Linley \& Joseph, 2007). Very limited number of scholars conceptualize trauma research in dialectical terms of a source for an emerging identity, characterized by the whole system of various outcomes including negative and positive as well as a motivation for sustainable change (Lomas \& Ivtzan, 2016; Wong, 2019). In this context PTG signifies development beyond the previous levels of functioning.

Despite a wide range of views on the interrelatedness between PTSD and PTG (Long et al, 2021; Shakespeare-Finch \& Lurie-Beck, 2014; Tedeschi \& Calhoun, 2004) we support the assertion that PTSD and PTG are not just separable and distinct or opposing stages of the recovery process but are systemically related to a 
dialectical cohesion within the construct of PTD which is known to have a certain rhythmic structure of transient elements: "thesis - antithesis - synthesis" (Hegel, 1969; Overton, 1994).

It is logical to presume that a traumatic event triggers the thesis of posttraumatic stress, which is the precondition for the antithesis of PTG. The latter opens up a perspective for the synthesis of a novel potential of personality. The personality is defined as an open psycho-social system communicating with its surroundings for the sake of its self-renewal and self-development, while development in itself is a process of a constant, spontaneous realization of personality system's potential in the form of emergent properties (Bertalanffy, 1972; Wieland-Burston, 2015). It seems appropriate to highlight the idea of the logical, not probabilistic nature of PTG in the course of surviving trauma, and the transition from post-traumatic stress to the emergence of a new personality system's potential (PTD). Recognizing this distinction, we should emphasize that the considerable part of PTG research still reduces positive outcomes of trauma to its random factors.

Tsukanov suggests that this cycle of development has rhythmical nature and is measured temporarily. In his empirical study he found a special subjective time unit, it coincides with an individual rhythm of heartbeat, walking, breathing and saccades (spontaneous eye movements). There is also a major and a minor cycle of personality development. It is measured by time periods of a major cycle ( $7+2$ years) and a minor cycle (about 2 years) (Cukhanov, 2000). This draws heavily on an individual's ability to change in a predictable and sustainable manner.

Available literature shows that as much as $90 \%$ of survivors of various forms of traumatic events experience positive change over time (Affleck et al, 1987; Tedeschi \& Calhoun, 2004). On the one hand, it implies that people are able to adapt to adversity, on the other - personality growth is not necessarily possible under the condition of leaving the comport zone. Positive psychology (PP) and psychological help $(\mathrm{PH})$ can be a great source for hope and optimism. This we consider not trivial - if people not just believe but actually change - this phenomenon of PTG is then worthy of special studies.

\section{Methods}

The current paper aims to expand our concept of positive changes in the aftermath of trauma through a dialectical understanding with a further attempt to provide practical implications for psychological practice.

A few cases of PTD will be discussed further. One of them relates to a wellknown narrative of the discovery of EMDR protocol. The other is the case from our own practice of PTD facilitation.

The study also included theoretical and empirical data analysis of psychological discourse in post-traumatic sphere of personality development, synthesis of definitions of post-traumatic development (PTD), PTSD, PTG, and mental health; ascending from the abstract to the concrete, theoretical modeling; reflective analysis of psychotherapeutic and counselling practices. 


\section{Results and Discussion}

\section{Reinterpretation of post-traumatic growth (PTG) and post-traumatic development (PTD): from the logic of probability to regularity}

In case we represent personality development in the form of a sine wave the occurrence of positive or negative events, processes can be shown graphically in a figure set out below (Fig. 1).

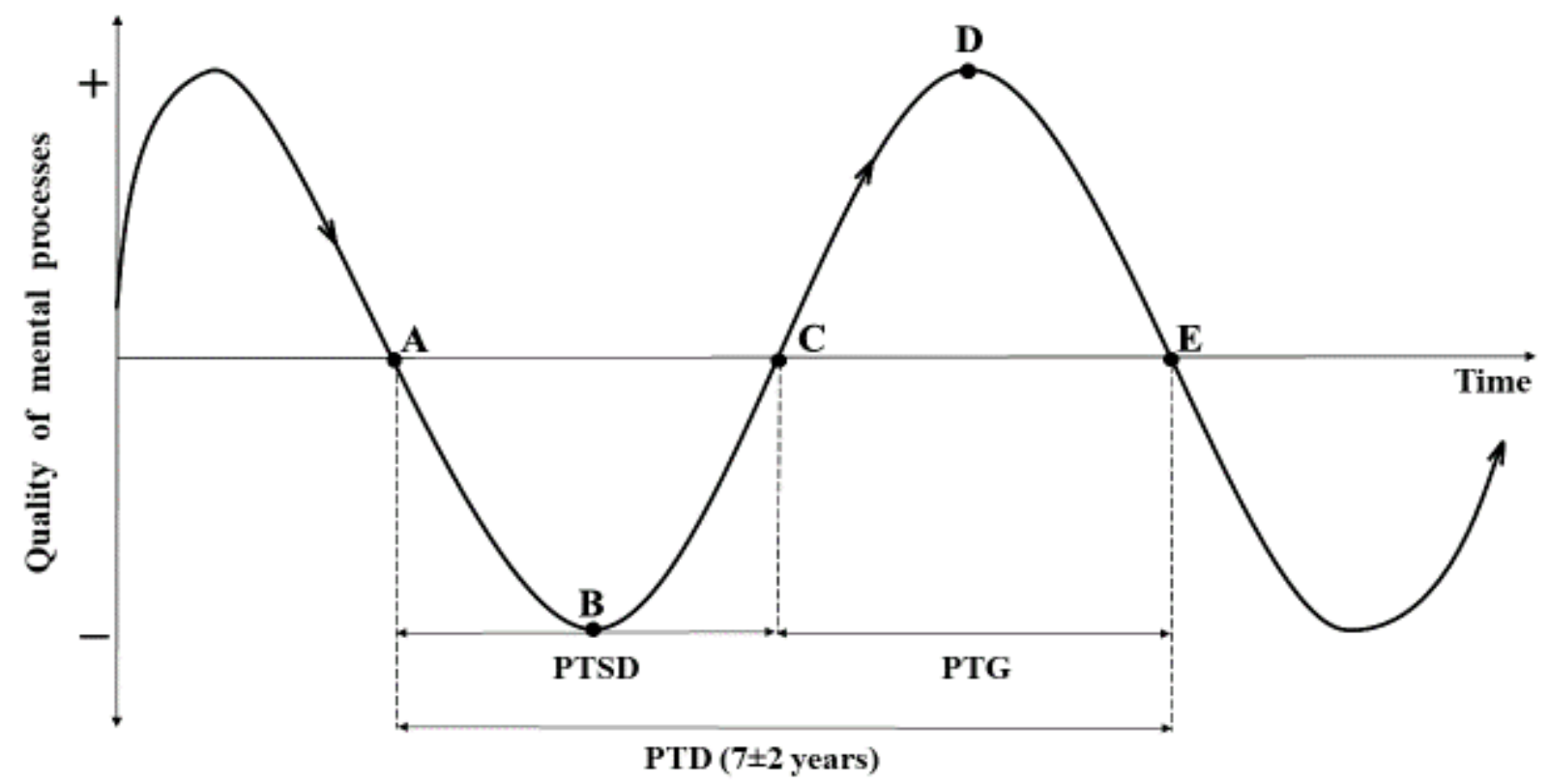

Figure 1.

Cycle of post-traumatic personality development

The full cycle of post-traumatic personality development can be divided into two sub-cycles marked by transient events and processes of a negative and positive character $(\mathrm{A}, \mathrm{B}, \mathrm{C}, \mathrm{D}, \mathrm{E})$. PTSD process is located under the $\mathrm{X}$-axis of this graph; consequently, PTG process is above it ( $\mathrm{X}$ is the axis of time, $\mathrm{Y}$ is the axis of quality of mental processes). This suggests that A, C, E events are mostly transient that is including mixed qualities, while $\mathrm{B}$ и $\mathrm{D}$ are predominantly negative and positive. Although it is quite logical to assume that all of the events could be defined in terms of a transient potential - each of them holding an impulse for a progressive change or an intrinsic program for proximal development. The fact is recognized by Overton (1994), who claims the personality is propelled forward not by a total but a partial success.

In the context of psychological help it is important to emphasize that there is hardly a sense in helping an individual to mainly reduce PTSD symptoms or facilitate PTG. We argue that both tasks could be viewed constructive in the context of change, when the personality system is advanced to new levels of development. 
In other words, PTD facilitation means helping to sustain the rhythm of system's self-organization within the whole range of experiences (from A to E) and onwards.

Much of the research has been dedicated to the analysis of the models of PTG (Christopher, 2004; Janoff-Bulman, 2004; Joseph \& Linley, 2004; Tedeschi \& Calhoun, 2004; Tedeschi \& Moore, 2020). The closest to dialectic understanding of PTG is the model of P. Wong (2019), the founder of the second wave of positive psychology. He supports the indissociable unity of negative and positive personality conditions (Wong, 2011; 2019). This position differs from the position of the proponents of the first wave of PP. Their major focus is on highlighting the difference between the positive and negative states in order to facilitate the latter which are happiness, optimism, resilience and, consequently, PTG (Csikszentmihalyi, 2012; Seligman, 2002). Dabrowski \& Wong's claim that the source of development could be associated with such paradoxical phenomena as "positive disintegration" (Mendaglio, 2008) and "tragic optimism" (Wong \& McDonald, 2002).

In this context we should emphasize that psychological help is not necessarily about creation of favorable conditions for positive outcomes in the aftermath of psychological trauma but ecological appreciation of the whole spectrum of human experience by sustaining the rhythm of personal development. Thus, we argue that an open personality system is a social ecosystem which in order to preserve itself resolves the contradictions between its various elements, including positive and negative with their unique role in promoting the system's wellbeing.

\section{Social psycho-immunity (SPI): dialectical metaphor of personality development and psychological help}

Describing psychological help $(\mathrm{PH})$ we share the metaphor of "the work of immunity system" elaborated by proponents of "developmental contextualism" (Davis \& Millon, 1994). We suggest that mental, social and physical organisms being closely interconnected constitute a self-regulated and self-organized ecosystem with a potential not only for fighting the deficiency of internal or external origin - as traditionally ascribed to an organism's immune system - but also for facilitating its growth and development, as well as thriving and stagnation. It is implied that the socio-psychological immunity is not only a defensive but proactive/creative entity. That means that the course of development is determined by the resolution of the basic contradiction between stability and change: as soon as the first starts to prevail (with certain signs of system's stagnation), the second tendency takes the lead in order to generate novel contexts to be appropriated (Kostyuk, 1989). An intent to present an open system as stable and absolutely predictable reduces its understanding to an inanimate, mechanic. In terms of SPI the only form of sustainability - as a major quality of full-functioning and health - is development, i.e. a constant change of emergents as novel forms of existence. In the context a condition of illness and a condition of health are normative, and are related to each other as "thesis - antithesis" in the course of generating a synthesis of new 
emergents and capacities. Following this, PTSD as well as PTG are transient, and complementary.

Encountering the complex, problematic situations can cause adequate immunity response that facilitates not just a relief or an adjustment but also strengthening of the socio-psychological immunity in the form of new "antibodies" (gene - antigen - antibody or thesis-antithesis-synthesis). Metaphorically speaking, the experience of living through the situations may build a "bank of antibodies" or socially relevant culture of capacities and self-healing trajectories.

The role of a psychologist is to support the process of self-help or SPI work. This also reflects the paradoxical nature of $\mathrm{PH}$ which is distributed. The psychologist functions as an "antigene" to the "gene" of the client's position which creates a certain contradiction to be resolved by forming a "social antibody" or a collective subject (that initiates a working alliance or rapport). Then follow another cycle of development - the emergence of new "thesis - antithesis" interactions which result in the synthesis of new possibilities, both for the client and psychologist. Thus, $\mathrm{PH}$ is a form of expansion of boundaries of client's selfregulation. SPI can be interpreted as a multilayer structure not reduced to exclusively biological or psychological function: "antigens" as well as "antibodies" could be of cross-cultural, transcendent and temporal origin.

This meta-analysis provides certain principles for PTG and PTD facilitation (Fig. 2).

1. Mental health is not just a condition/a state but a process of constant renewal of the open self-regulatory personality ecosystem, which is personality development.

2. Development has a certain rhythmic structure: thesis - antithesis - synthesis or in terms of immunity metaphor: gene - antigene - antibody.

3. Every element in the developmental structure has transient nature and contains a program/impulse for transition to a new stage of development. The helping agent facilitates both explication and flow of the elements.

4. Immune system has a multilayer character: biological, psychological, social, transcendent, temporal, etc. All of the levels create an ecosystem of an unlimited resource for change.

5. SPI has a dual nature - it is both a defensive and a creative mechanism of selfpreservation and growth.

6. The major task of psychological help is to facilitate growth and development by sustaining the rhythm/flow of transient forms.

7. These transient forms can present themselves unpredictably in paradoxes, accidental events or spontaneous metamorphoses.

8. There is no sense in defining SPI in terms of strength or weakness. It functions in accordance with a certain context. The major attribute of SPI is sustainability of change.

9. The principle of irreversibility. It is impossible for a personality ecosystem to transit to the previous level of development. Psychologist facilitates the advancement of the ecosystem to new levels of development.

\section{Figure 2.}

Principles of PTG and PTD facilitation 
All of the above-mentioned principles of $\mathrm{PH}$ determine practical implications for dealing with the experience of the post-traumatic issues. In the next section we would analyze a few cases which, on the one hand reflect natural spontaneity of PTD, and, on the other - illustrate practical aspects of eco-centered facilitation ("ecofacilitation") in the aftermath of traumatic events (Lushyn, 2017).

\section{Post-traumatic development and growth: implications for positive psychology practice}

Further we will provide a few cases of PTD, one of them relates to a wellknown narrative of the discovery of EMDR protocol (a psychotherapeutic technique for trauma processing) (Shapiro, 1995). The other is the case from our own practice of PTD facilitation.

Being a successful philologist, Shapiro was diagnosed with cancer. After the operation the perspectives of full recovery at that time were vague. She decided to take up the challenge by exploring self-healing practices which in some time brought her to psychotherapy as her future occupation. One day during a walk in the park she had an insight associated with the role of saccades (involuntary eye movements) in reducing intrusive ruminations. This provided the key element to the protocol for trauma processing (Eye Movement Desensitization and Reprocessing EMDR) (Shapiro,1995).

Surprisingly, a Ukrainian psychologist Tsukanov had a similar experience: he experimented with a treatment of psychosomatic illnesses based on the assessment of client's subjective time unit (Tsukanov, 1989; Cukanov, 2000) and found the internal clock has a certain "pendulum" swinging at an individual pace which corresponded to the rhythm of saccades, normal heartbeat, walk or breathing. Irregular rhythm signified a certain probability of pathological processes. To eliminate them he came up with a defibrillation technique which consisted in client's following the rhythm of her normal pace of breathing or saccades set out with the help of a metronome. EMDR protocol and defibrillation technique seem similar with an only exception that the practitioners used different tools (metronome or a hand empirically adjusted to the client's rhythm of saccades).

In both therapeutic approaches the traumatic phase can be reinterpreted in terms of constructive psychosomatic transition within a temporal level of the SPI: regular rhythm (gene) of subjective clock generates the opposite time mode of fibrillation (antigene) to complete the process by a natural or socially induced additional impulse (synthesis).

Our long-standing psychotherapy practice proves that some highly motivated clients display a certain determination to follow their own individual trajectory of response following trauma. This reveals itself in well-structured time predictors of their effective growth and PTD. Often the client takes the initiative to administer the upcoming session as if having been informed of its content and even timing. This also relates to their acute estimation of the therapist's capacity to tolerate uncertainty and follow unpredictable turns of client's course of self-direction. 
In particular, a middled aged woman, over 40, survived multiple traumatic events within a relatively small time period. One of the traumatic events related to her job loss, the other to her divorce, and the third was the case of a serious complication of alcoholism disorder on the part of a very close relative of hers. An important request she made before the beginning of her therapy session was the work in front of a group of people. During the session some other paradoxes emerged. The first one was she took a sit she could both turn to the audience and the therapist. Despite the periodic remarks to take a more direct position towards the psychologist, she resumed the preferred dual position. Then she seemed to be very sensitive to monitoring the time of the session: the client took most of the time for a very emotional narrative of her traumatic experiences - which could have been quite appropriate within an individual setting of the session but not quite adequate to the time restriction of the public event. The client produced an impression of overlooking the therapist's remarks as to the timing of her narration, although, once she directly rejected the remarks by "we can make it" response. Besides, the client even seemed to have correctly "diagnosed" the therapist's inclination to follow her individual trajectory which she fully used to her advantage. All of these paradoxes were resolved in a rather unexpected closure of the session.

In 15 minutes before the ending of the session the client addressed the psychologist with sincere apologies and an accurate explanation of her responses during the session. She admitted that her intention was to keep a good feedback not only from the psychotherapist but from the audience who, to her surprise, turned out to be very accepting. That explained her being persistent in taking a dual sitting position. She also expressed a few appreciative remarks as to the dynamic of the session and the therapist's tolerance which she had never experienced before. Finally, the woman presented a thorough analysis of her numerous insights during the session. It took her less than five minutes to dwell on her responsibility for the job loss: "Since my childhood I have been dreaming of becoming a professional artist... my dad used to tell me of my talent... at last I am very close to my dream come true". Emotional part of the narrative grew very positive. She spoke of her other insight - "recently without being aware of the practical task I resumed improving my artistic skills... now I am aware what it was all about!". By this she found that the traumatic event and its subsequent resolution had been unconsciously prepared beforehand. This and other awarenesses had a very reassuring realization in the life of the client. We learned from social media and our informal communications that her psychological issues disappeared; she started a successful career of a professional artist. This change brought about a considerable transformation of her lifestyle, and some relevant improvements in her social ecosystem of friends and her close relatives ${ }^{1}$.

\footnotetext{
${ }^{1}$ The description of the PTG cases and the principles of PTG facilitation are consistent with psycholinguistic research (Luno, Louwerse, \& Beck, 2013, Mansfield, McLean, \& Lilgendahl, 2010, Pereira, Sampson, \& DiCola, 2019, Kleim, Horn, Kraehenmann, Mehl, \& Ehlers, 2018, Busch \& McNamara, 2020) providing the foundation for our building a special psycholinguistic study designed to validate of the proposed PTG model (fig.1).
} 
This and other cases from our extended therapeutic practice suggests that a request for $\mathrm{PH}$ and the narrative of the traumatic experience incorporate not only the content of an individual healing trajectory but the unfolding of client's temporal perspective. The essential prerequisite on the part of the psychotherapist is ambiguity tolerance or following the process as it goes. This drives us to the conclusion that $\mathrm{PH}$ is (a) not so much the beginning of the transformative process but its closure, the realization of a pre-given personality potential, (b) it is a form of non-linear, often accidental advancements.

In this context we claim that the suggested dialectical approach to PTD facilitation has a certain relevance for the process of strengthening the SPI of a social ecosystem. In "industrial" terms of Joseph (Joseph, 2011) there are growing signs of a transition from a "PTSD industry" that leaves no space for natural recovery of the PTSD survivor to the alternative or antithetic "PTG industry", which targets at exclusively positive and spontaneous resolutions of traumatic issues. To our estimation the current world of unpredictability and ambiguity lays the foundation for the emerging "industry of ambiguity" (Lushyn, 2020; Lushyn, Sukhenko, \& Davydova, 2020). The latter builds on the previous forms of social reconstruction presuming that ambiguity is no longer a "bug but a feature" of personal and social development. For example, the approach presupposes that "culture of illness" and mental disorder are not necessarily associated with a need for adaptation to certain deficits/restrictions or on the contrary - with antithetic resort to hedonistic wellbeing, optimism and happiness ("culture of health"). "Ambiguity or PTD industry" integrates the stability of change as a symbol of a new reality ("the culture of the emerging"). The current pandemic of COVID-19 closes the narrative of system restoration in favor of the narrative of a non-linear and irreversible self-organization. In SPI terms the medical and pharmaceutical responses are complemented with social "antibodies" on deferent levels of politics ("a COVID-19 certificate"), technology (zoom distant learning and teaching, online clubhouse culture), innovative psychotherapeutic modalities, and internet marketing, etc. "Industry of Ambiguity" reveals itself in newest mindsets and memes: "there is no turning back to old life", "emergence of unfamiliar virus strains is a new reality to be harnessed or used to advantage". PTSD treatment is no longer about resuming the old life-style or improving the wellbeing but about a sustainability of unpredictable change of perspectives.

The facilitator of change becomes a "social immunologist" who fulfills the metamodern design of a therapeutic modality (Gardner, 2016; Lushyn, 2017) which could be described as so: there is no former stability - constant change is a new normality; every element of a social ecosystem could be a resource and an agent of self-organization of the systemic change; universal regularities and rules are local and restricted by a certain context; development of the ecosystem unfolds as a communication with a confronting or antithetic surroundings; problem is a new possibility; no zeroing or underestimation of the past, its value is priceless. 


\section{Conclusions}

The process of personality change as development is paradoxical, irreversible and scarcely predictable. In dialectical perspective the attractors of change are not the content of transient forms but the stabilization of their change. As compared to PTG, PTD's outcome is the systemic transition to an emerging (not better or positive) identity, when the personal surroundings grow, on the one hand, problematic, non-transparent, on the other - stimulating and encouraging further advancement.

PTSD as well as PTG minor cycles of personal development constitute a dialectical unity within its major cycle of PTD. Their flow has a rhythmic structure. In this context the cycle of PTG culminates in paradoxical signs of both the exhaustion of the previous personality potential and the explication of a new one. Then follows the cycle of unpredictability and an ambiguous change attracted to the emergence of paradoxical phenomena, such as "tragical optimism", "constructive pathology" and "PH as a social level of personal self-regulation".

The core metaphor of change as personality development is SPI or the work of the immunity system which also has an ambivalent nature (it defends the personality from adversarial agents and proactively guards it from stagnation). SPI is a multifaceted dynamic structure, which transcends the organismic level of functioning for social, psychological and temporal levels. The dialectical nature of SPI is determined by a capacity to communicate with antagonistic agents in order to synthesize social and psychological "antibodies"/resources.

Principals of PTD facilitation: $\mathrm{PH}$ is a situation of a personal transition to a social level of self-regulation. The inquiry for $\mathrm{PH}$ contains the narrative with elements for post-traumatic growth and development. These elements are pre-given as paradoxes, contradictions, incongruences as sources of development. The major task of the PTD is to support the explication of internal programs for change.

The important prerequisite of PH for PTD facilitation is the antithetic position of the facilitator. It could be characterized in terms of an emerging "Ambiguity or PTD industry" which consists in generating new patterns of self-organization on the basis of the newest metamodernist model. In terms of the provided PTD model it suggests (a) traumatic event could be a precondition for irreversible change for personality development; (b) the post-traumatic process is ambiguous and is revealed in the flow of relatively positive and negative transient forms; (c) one of them is an experience of a total impasse or a block of the facilitation process; (d) sensitivity to accidental events and the rhythm of their change.

The provided model of PH for PTD facilitation could be regarded as antithetic to the prevailing medical model. In its essence it is a metamodernistic synthesis to the conflict between modern and post-modern social and cultural orientations. The social demand and the dissemination of the approach could stimulate the generation of a novel potential in the sphere of psychological practices.

The perspectives of our future research we associate with empirical validation of the suggested dialectical model of PTG within a set of psycholinguistic experiments 
directed at the study of predictors of PTG and psycholinguistic representation of its effective facilitation.

\section{References}

Affleck, G., Tennen, H., Croog, S., \& Levine, S. (1987). Causal attribution, perceived benefits, and morbidity after a heart attack: An 8-year study. Journal of Consulting and Clinical Psychology, 55, 29-35. https://doi.org/10.1037/0022-006X.55.1.29

American Psychiatric Association. (2013). Diagnostic And Statistical Manual of Mental Disorders, 5th Edition. https://doi.org/10.1176/appi.books.9780890425596

Bertalanffy, L. (1972). The History and Status of General Systems Theory. The Academy of Management Journal, 15(4), 407-426. http://www.jstor.org/stable/255139

Brown, L., Belli, G., Asnaani, A., \& Foa, E. (2019). A review of the role of negative cognitions about oneself, others, and the world in the treatment of PTSD. Cognitive Therapy and Research, 43(1), 143-173. https://doi.org/10.1007/s10608-018-9938-1

Busch, B., \& McNamara, T. (2020). Language and Trauma: An Introduction. Applied Linguistics, 41(3), 323-333, https://doi.org/10.1093/applin/amaa002

Christopher, M. (2004). A broader view of trauma: A biopsychosocial-evolutionary view of the role of the traumatic stress response in the emergence of pathology and/or growth. Clinical Psychology Review, 24(1), 75-98. https://doi.org/10.1016/j.cpr.2003.12.003

Cohena, A., \& Baib, H. (2019). Eastern wisdom, inner work, and aging: a contribution in second wave positive psychology. Counselling Psychology Quarterly, 32(3-4), 472-487. https://doi.org/10.1080/09515070.2019.1624253

Csikszentmihalyi, M. (2012). FLOW: The Psychology of Optimal Experience. Harper \& Row.

Cukanov, B. (2000). Vremja v psihike cheloveka [Time in the human psyche]. Odessa: Astroprint.

Davis, R., \& Millon, T. (1994). Personality change: Metatheories and alternatives. In:

T. Heatherton \& J. L. Weinberger (Eds.), Can personality change? (p. 85-119). American Psychological Association. https://doi.org/10.1037/10143-005

Ertan, D., Hingray, C., Burlacu, E., Sterlé, A., \& El-Hage, W. (2021). Post-traumatic stress disorder following childbirth. BMC Psychiatry, 21, 155. https://doi.org/10.1186/s12888$\underline{021-03158-6}$

Gardner, L. (2016). Metamodernism: A New Philosophical Approach to Counseling. Journal of Humanistic counseling counseling, 55(2), 86-98. https://doi.org/10.1002/johc.12026

Hegel, G. (1812/1969). Science of Logic. London: George Allen and Unwin.

Janoff-Bulman, R. (2004) Posttraumatic Growth: Three Explanatory Models. Psychological Inquiry, 15(1), 30-34. https://www.jstor.org/stable/20447198

Joseph, S. (2011). What Doesn't Kill Us: The New Psychology of Posttraumatic Growth. Basic Books.

Joseph, S., \& Linley, P. (2004). Positive change following trauma and adversity: A review. Journal of Traumatic Stress, 17, 11-21.

Kleim, B., Horn, A., Kraehenmann, R., Mehl, M., \& Ehlers, A. (2018). Early Linguistic Markers of Trauma-Specific Processing Predict Post-trauma Adjustment. Frontiers in Psychiatry, 9, 645. https://doi.org/10.3389/fpsyt.2018.00645

Kostyuk, H. (1989). Navchal'no-vyhovnyj proces i psyhichnyj rozvytok osobystosti [Learning Process and Mental Development of a Personality]. L. Prokolijenko, Ed. Kyiv: Radianska Shkola.

Lomas, T., \& Ivtzan, I. (2016). Second Wave Positive Psychology: Exploring the PositiveNegative Dialectics of Wellbeing. Journal of Happiness Studies, 17, 1753-1768. https://doi.org/10.1007/s10902-015-9668-y 
Long, L., Phillips, C., Glover, N., Richardson, A., D’Souza, J., Cunningham-Erdogdu, P., \& Gallagher, M. (2021). A Meta-analytic Review of the Relationship Between Posttraumatic Growth, Anxiety, and Depression. Journal of Happiness Studies: An Interdisciplinary Forum on Subjective Well-Being. Advance online publication. https://doi.org/10.1007/s10902-021-00370-9

Luno, J., Louwerse, M., \& Beck, J. (2013). Tell us your story: Investigating the linguistic features of trauma narrative. In M. Knauff, M. Pauen, N. Sebanz, \& I. Wachsmuth (Eds.), Proceedings of the 35th Annual Conference of the Cognitive Science Society (CogSci). The Cognitive Science Society. (2955-2960).

Lushin, P. (2017). Haos i neopredelennost': ot stradanija - $k$ rostu i razvitiju [Chaos and ambiguity: from suffering to growth]. Kiev. (Serija «Zhivaja kniga»; T. 4).

Lushyn, P. (2020). At the forefront of the buffer: the convergence of traditional and positive psychology Psychological Counseling and Psychotherapy, 14, 28-34. https://doi.org/10.26565/2410-1249-2020-14-0

Lushyn, P., Sukhenko Ya., \& Davydova, O. (2020). Particularities of Students' Educational Trajectories and "Projectories": A Psychosemantic Dimension. In 2020 IEEE Problems of Automated Electrodrive. Theory and Practice (PAEP). Kremenchuk, Ukraine: IEEE. http://dx.doi.org/10.1109/PAEP49887.2020.9240866

Mansfield, C., McLean, K., \& Lilgendahl, J. (2010). Narrating traumas and transgressions: Links between narrative processing, wisdom, and well-being. Narrative Inquiry, 20(2), 246-273. https://doi.org/10.1075/ni.20.2.02man

Mendaglio, S. (Ed.). (2008). Dabrowski's theory of positive disintegration. Great Potential Press, Inc.

Overton, W. (1994). The Arrow of Time and the Cycle of Time: Concepts of Change, Cognition, and Embodiment. Psychological Inquiry, 5(3), 215-237. https://doi.org/10.1207/s15327965pli0503_9

Pereira, L., Sampson, J., \& DiCola, K. (2019). Factors Related to Linguistic Content in Video Narrative of Adolescents with Cancer and Healthy Controls. Journal of Psycholinguistic Research, 48, 1185-1201. https://doi.org/10.1007/s10936-019-09652-Z

Rowen, J. (1992). The Concept of breakthrough. In Breakthrough and Integration in Psychotherapy. (pp. 81-83). London: Whurr Publishers LTD.

Seligman, M. (2002). Authentic happiness: Using the new positive psychology to realize your potential for lasting fulfillment. New York: Free Press.

Shakespeare-Finch, J., \& Lurie-Beck, J. (2014). A meta-analytic clarification of the relationship between posttraumatic growth and symptoms of posttraumatic distress disorder. Journal of Anxiety Disorders, 28(2), 223-229. https://doi.org/10.1016/j.janxdis.2013.10.005

Shapiro, F. (1995.) Eye movement desensitization and reprocessing: basic principles, protocols, and procedures. New York: The Guilford Press.

Stein, Dan J. et al. (2020). Perceived helpfulness of treatment for posttraumatic stress disorder: Findings from the World Mental Health Surveys. Depression and Anxiety, 37(10), 972974. https://doi.org/10.1002/da.23076

Tedeschi, R., \& Moore, B. (2020). Posttraumatic Growth as an Integrative Therapeutic Philosophy. Journal of Psychotherapy Integration. Advance online publication. http://dx.doi.org/10.1037/int0000250

Tedeschi, R., \& Calhoun, L. (2004). Posttraumatic growth: Conceptual foundations and empirical evidence. Psychological Inquiry, 15, 1-18. http://dx.doi.org/10.1207/s15327965pli1501_0

Tsukanov, B. (1989). Time Factor and the Problem of Cardiovascular Diseases. The Soviet Journal of Psychology, 1, 53-59.

Wieland-Burston, J. (2015). Chaos and Order in the World of the Psyche. London: Routledge.

Wong, P. \& McDonald, M. (2002). Tragic optimism and personal meaning in counselling victims of abuse. Pastoral Sciences, 20(2), 231-249. 
Wong, P. (2011). Reclaiming Positive Psychology: A Meaning-Centered Approach to Sustainable Growth and Radical Empiricism. Journal of Humanistic Psychology, 51(4) 408-412. https://doi.org/10.1177/00221678114087299

Wong, P., (2019). Second wave positive psychology's (PP2.0) contribution to counselling psychology. Counselling Psychology Quarterly, 32(3-4), 275-284.

https://doi.org/10.1080/09515070.2019.1671320. 